\title{
UPAYA MENINGKATKAN KECERDASAN NATURALIS MELALUI KEGIATAN BERCOCOK TANAM DI BAMBIM AL-ABROR KECAMATAN MANGKUBUMI KOTA TASIKMALAYA
}

\author{
Yasbiati $^{1}$, Rosarina Giyartini ${ }^{2}$, Anisa Lutfiana ${ }^{3}$, \\ ${ }^{1}$ Program Studi PGPAUD UPI Kampus Tasikmalaya \\ ${ }^{2}$ Program Studi PGSD UPI Kampus Tasikmalaya \\ ${ }^{3}$ Program Studi PGPAUD UPI Kampus Tasikmalaya \\ Email: yasbiati@upi.edu
}

(Received: September 2017; Accepted: Oktober 2017; Published: Desember 2017)

\begin{abstract}
This study aims to improve the naturalist intelligence of children through planting activities in BAMBIM AlAbror mangkubumi district Tasikmalaya City. Naturalist intelligence can be enhanced by various activities that are directly related to nature, or introducing objects that would stimulate the child's naturalist intelligence. This research is a Classroom Action Research. The subjects of this study were 11 children in BAMBIM Al-Abror, with a total of 7 girls and 4 boys. This study consists of 3 cycles. The results of this study indicate an increase in the naturalist intelligence of children in BAMBIM Al-Abror by using planting activities, the end result of child's naturalist intelligence in BAMBIM Al-Abror as the first indicator shows the pleasure of the plant has a significant increase with the final ability of $9.09 \%$ on the criteria begin to develop, $45.45 \%$ on the criteria developed as expected, and $45.45 \%$ on the criteria developed very well. The second indicator that is to distinguish the parts of the plant gets an improvement with the final ability of $18.18 \%$ on the criteria begin to develop, $45.45 \%$ on the criteria devolved as expected and 36.365 on the criteria develop very well. The third indicator of ability to look after the plants has increased with the final ability of $9.09 \%$ on the criteria begin to develop, $54.54 \%$ on the criteria developed as expected and $36.36 \%$ on the criteria develop very well. The fourth indicator of planting activities also increases with the final ability of $9.09 \%$ on the criteria developed as expected and $72.72 \%$ on the criteria developed very well.
\end{abstract}

Keywords: Naturalist Intelligence, Planting

\begin{abstract}
ABSTRAK
Penelitian ini bertujuan untuk meningkatkan kecerdasan naturalis anak melalui kegiatan bercocok tanam di BAMBIM Al-Abror kecamatan mangkubumi Kota Tasikmalaya. Kecerdasan naturalis dapat ditingkatkan dengan berbagai kegiatan yang berhubungan langsung dengan alam, seperti kegiatan bercocok tanam. Penelitian ini merupakan Penelitian Tindakan Kelas. Subyek penelitian ini adalah anak di BAMBIM Al-Abror sebanyak 11 orang anak, dengan jumlah 7 orang anak perempuan dan 4 orang anak laki-laki. Penelitian ini terdiri dari 3 siklus. Hasil Penelitian ini menunjukan adanya peningkatan kecerdasan naturalis anak di BAMBIM Al-Abror dengan menggunakan kegiatan bercocok tanam, hasil akhir kecerdasan naturalis anak di BAMBIM Al-Abror sebesar indikator pertama menunjukan kesenangan terhadap tanaman mengalami peningkatan yang signifikan dengan kemampuan akhir sebesar 9,09\% pada kriteria Mulai berkembang, 45,45\% pada kroteria berkembang sesuai harapan, dan 45,45\% pada kriteria berkembang sangat baik. Indikator kedua membedakan bagian-bagian tanaman menalami peningkatan dengan kemampuan akhir sebesar 18,18\% pada kriteria mulai berkembang, $45,45 \%$ pada kriteria berkembang sesuai harapan dan 36,365 pada kriteria berkembang sangat baik. Indikator ketiga kemampuan merawat tanaman mengalami peningkatan dengan kemampuan akhir sebesar 9,09\% pada kriteria mulai berkembang, 54,54\% pada kriteria berkembang sesuai harapan dan 36,36\% pada kriteria berkembang sangat baik. Pada indikator keempat melakukan kegiatan menanam juga mengalami peningkatan dengan kemampuan akhir sebesar 9,09\% pada kriteria berkembang sesuai harapan dan 72,72\% pada kriteria berkembang sangat baik.
\end{abstract}

Kata kunci: Kecerdasan Naturalis, Kegiatan Bercocok Tanam 


\section{PENDAHULUAN}

Anak usia dini adalah manusia yang sedang berada pada rentang usia 0-8 tahun, yang memiliki potensi yang masih harus dikembangkan. (Sujiyono, 2013, hlm. 6). Menurut chatib setiap anak memiliki karakteristik tertentu yang khas dan tidak sama dengan anak lainnya, bahkan dua orang kembar sekalipun memiliki karakter yang berbeda.

Pendapat bahwa semua anak cerdas dan bahwa anak memiliki cara yang tidak selalu sama untuk menjadi cerdas adalah proposisi dasar teori multiple intelligence, proposisi dasar teori kecerdasan majemuk harus dipahami dan diyakini oleh setiap pendidik di lembaga PAUD. Pendidik harus tahu dan yakin bahwa setiap anak memiliki kecerdasan dan tugas guru adalah memberikan stimulasi atau rangsangan yang berbeda agar anak didik berkesempatan memunculkan serta mengembangkan setiap indikator kecerdasan yang dimilikinya.

Gardner dalam Chatib dan Said (2014, hlm. 79) kembali menghasilkan karya intelektual berjudul Intelligence Reframed yang menyatakan bahwa otak manusia setidaknya menyimpan sembilan jenis kecerdasan yang disepakati, yang terdiri dari: Kecerdasan linguistik, Kecerdasan logika-matematika, kecerdasan visual-sppasial, kecerdasan kinestetik, kecerdasan musik, kecerdasan interpersonal, kecerdasan intrapersonal, kecerdasan naturalis dan kecerdasan eksistensial.

Kecerdasan naturalis adalah salah satu dari sembilan kecerdasan yang disebutkan oleh Howard Gardner, Kecerdasan naturalis merupakan kemampuan seseorang yang menunjukkan kemahiran dalam mengenali dan mengklasifikasikan banyak spesies (flora dan fauna) dalam lingkungannya (Armstrong, 2002, hlm. 212), mengenali eksistensi suatu spesies, memetakan hubungan antara beberapa spesies, meliputi kepekaan pada fenomena alam lainnya (formasi awan, gunung), membedakan benda tak hidup dan kemampuan merasakan bentuk-bentuk serta menghubungkan elemen-elemen yang ada di alam (Yuliani Nurani Sujiono, 2013, hlm. 194).

Kecerdasan naturalis anak pada usia 4-6 tahun muncul dalam bentuk sudah mulai memiliki rasa kepekaan terhadap lingkungan sekitar, mereka sudah memiliki minat terhadap alam (dengan mengamati, terlibat, mencermati gambar, mengoleksi unsur tumbuhan/hewan), merawat dan memelihara hewan/tumbuhan, mendokumentasikan melalui gambar, dan mencari informasi melalui bertanya, melihat tayangan, dan membaca (Tadkiroatun Musfiroh, 2010, hlm. 8.7).

Menurut hasil observasi pada akhir semester 1 tahun pelajaran 2016/2017 di BAMBIM Al-Abror, diperoleh data bahwa dari 11 anak hampir sebagian besar masih menunjukkan kurangnya perhatian terhadap lingkungannya. Terlihat mereka membuang sampah sembarangan hanya ada 2 orang anak yang membuang sampah pada tempatnya, memetik tanaman seenaknya, dan menelantarkan tanaman yang sudah layu. dengan perilaku tersebut dapat dikatakan bahwa anak di BAMBIM Al-Abror perlu mendapatkan rangsangan untuk dapat meningkatkan kecintaannnya terhadap lingkungan sekitarnya.

Melihat dari permasalahan di atas, maka cara untuk mengatasinya adalah dengan mulai mengenalkan dan mendekatkan anak dengan alam melalui kegiatan-kegiatan yang langsung berkaitan dengan alam. Hal tersebut dimaksudkan agar anak-anak dapat lebih dekat dan menyatu dengan alam serta dapat ikut memelihara alam di sekitar mereka. Di samping itu juga disertai dengan merubah metode pembelajaran yang masih monoton dengan pembelajaran yang lebih bervariasi dan menarik perhatian anak, sehingga dapat merangsang anak untuk mengembangkan kecerdasannya.

\section{TINJAUAN PUSTAKA}

\section{Pendidikan Anak Usia Dini}

Anak usia dini adalah manusia yang sedang berada pada rentang usia 0-8 tahun, yang memiliki potensi yang masih harus dikembangkan (Sujiyono, 2013, hlm. 6). Setiap anak memiliki karakteristik tertentu 
yang khas dan tidak sama dengan anak lainnya, bahkan dua orang kembar sekalipun memiliki karakter yang berbeda. Menurut Undangundang Nomor 20 tahun 2003 tentang sistem pendidikan nasional berkaitan dengan pendidikan anak usia dini pada pasal 28 ayat 1 yang menyatakan "pendidikan anak usia dini diselenggarakan bagi anak sejak lahir hingga usia enam tahun dan bukan merupakan prasyarat untuk mengikuti pendidikan dasar".

Selanjutnya pada bab 1 pasal 1 ayat 14 dijelaskan bahwa pendidikan anak usia dini adalah suatu upaya pembinaan sejak lahir hingga usia enam tahun yang dilakukan melalui pemberian rangsangan pendidikan untuk membantu pertumbuhan dan perkembangan jasmani dan rohani anak agar memiliki kesiapan dalam mengikuti jenjang pendidikan yang lebih lanjut. (Sujiyono, 2013, hlm. 6).

Berdasarkan jurnal PADU (dalam Diana Mutiah, 2012, hlm. 7) anak usia dini dikelompokkan ke dalam

beberapa tahapan usia yaitu masa bayi di antara usia 0-12 bulan, masa batita (toddler) di antara usia 2-3 tahun, masa prasekolah (early childhood) di antara usia 4-6 tahun, dan masa kelas awal SD di antara usia 6-8 tahun. Dengan demikian dapat dinyatakan bahwa anak usia dini yang berusia 4-5 tahun adalah masa anak usia dini atau anak prasekolah.

\section{Perkembangan kecerdasan anak usia 4- 5 tahun}

Pada peraturan pemerintah, nomor 137 tahun 2014 ada enam Aspek perkembangan yang dapat dikembangkan pada usia 4-5 tahun diantaranya, Nilai agama dan moral; fisik motorik; kognitif; bahasa; sosial emosional dan seni.

Perkembangan kecerdasan anak usia dini salah satunya berkaitan dengan kemampuan kognitifnya, kemampuan tersebut dapat dikembangkan dengan menggunakan metode demonstrasi. Metode demonstrasi adalah suatu penyajian dengan penjelasan lisan disertai perbuatan atau memperlihatkan suatu proses tertentu yang kemudian diikuti atau dicoba oleh anak didik. Selain metode demonstrasi, metode tanya jawab juga dapat mengembangkan kemampuan kognitif anak dengan cara guru memberikan pertanyaan untuk dijawab oleh anak dan memberikan rangsangan agar anak aktif dan menjawab pertanyaan.

\section{Kecerdasan Majemuk}

Menurut Howard Gardner

ada 3 pengertian kecerdasan, diantaranya: kecerdasan adalah sebagai ciri khas spesies, kecerdasan adalah sebagai perbedaan individu, dan kecerdasan adalah sebagai bentuk eksplorasi dari masing-

masing individu.

Kecerdasan majemuk (multiple intelligences) yang dicetuskan pertama kali oleh Gardner berjumlah 7 jenis kecerdasan, diantaranya yaitu: (Howard Gardner, 1993, hlm. 8-16)

a.Musical intelligence (Kecerdasan musikal)

b.Bodily-kinesthetic intelligence (Kecerdasan Kinestetik)

c. Logical-mathematical intelligence

(Kecerdasan logis matematis)

d.Linguistic intelligence (Kecerdasan linguistik)

e. Spatial intelligence (Kecerdasan ruang)

$f$. Interpersonal intelligence (Kecerdasan interpersonal)

g.Intrapersonal intelligence (Kecerdasan intrapersonal)

Namun seiring dengan perkembangan pengetahuan, multiple intelligence ini dikembangkan lagi sehingga kini berkembang menjadi 9 kecerdasan. Kecerdasan dikembangkan lagi ke dalam bentuk kecerdasan naturalis dan kecerdasan eksistensi. (Paul Suparno, 2013).

Dari sembilan kecerdasan yang dicetuskan oleh Howard Gardner di atas, Kecerdasan naturalis adalah salah satu dari sembilan kecerdasan yang disebutkan oleh Howard Gardner, Kecerdasan naturalis merupakan kemampuan seseorang yang menunjukkan kemahiran dalam mengenali dan mengklasifikasikan banyak spesies (flora dan fauna) dalam lingkungannya (Armstrong 2002:212), mengenali eksistensi suatu spesies, memetakan hubungan antara beberapa spesies, meliputi kepekaan pada fenomena alam lainnya (formasi awan, gunung), membedakan 
benda tak hidup dan kemampuan merasakan bentuk-bentuk serta menghubungkan elemenelemen yang ada di alam (Yuliani Nurani Sujiono, 2009, hlm. 194).

\section{Kecerdasan Naturalis}

a. Pengertian Kecerdasan Naturalis

Kecerdasan naturalis adalah kemampuan dalam melakukan kategorisasi dan membuat hierarki terhadap keadaan organisme seperti tumbuh-tumbuhan, binatang dan alam. Pada dasarnya kecerdasan naturalis, kecerdasan berbasis alam.

Menurut Thomas, dkk. (2010, hlm.227) The Naturalist Intelligence was the eighth intelligence identified by Howard Gardner. He thought of it as a way to describe those who sort, categorize, and draw on the natural environment. In the distant past the Naturalist Intelligence helped people to survive; they knew what plants they could eat, when to sow seeds, and how to use natural cures.

Jadi kecerdasan naturalis adalah salah satu dari kecerdasan majemuk yang dicetuskan oleh Howard Gardner, menurut Gardner kecerdasan naturalis merupakan kemampuan untuk mengenali, membedakan, mengungkapkan dan membuat kategori terhadap apa yang dijumpai di alam maupun lingkungan. Di masa lalu yang memiliki kecerdasan naturalis yaitu mereka yang membantu orang-orang untuk bertahan hidup, mereka tahu makanan apa yang bisa dimakan dan bagaimana menggunakan obat alami.

Menurut Amstrong dalam Zaenal (2016 hlm 10), mengemukakan bahwa kecerdasan naturalis merupakan keahlian dalam mengenali dan mengklasifikasikan berbagai spesies flora dan fauna, dari sebuah lingkungan Individu. hal ini juga mencakup kepekaan terhadap fenomena alam lainnya (misalnya, formasiformasi awan, gunung, dll), dan dalam kasus tumbuh di lingkungan perkotaan, kemampuan untuk membedakkan benda-benda mati seperti mobil, sepatu, dan sampul CD (compact disc).

Dari pengertian kecerdasan naturalis di atas, peneliti menyimpulkan bahwa kecerdasan naturalis adaalah kecerdasan akan rasa peduli terhadap lingkungannya, misalnya menyiram tanaman, membuang sampah ke tempatnya agar lingkungan terlihat indah, menyayangi binatang yang ada di lingkungannya.

b. Ciri-ciri kecerdasan naturalis pada anak usia dini

Armstrong dalam Musfiroh (2010, hlm. 8.5) Anak-anak yang memiliki kecerdasan naturalis tinggi cenderung menyukai alam terbuka, mereka memiliki keingintahuan yang besar tentang seluk beluk hewan dan tumbuhan. Ibrahim \& yaumi (2016, hlm. 177) mengungkapkan bahwa anak yang memiliki ciri-ciri kecerdasan naturalis adalah kesenangan mereka pada alam, binatang, misalnya akan berani mendekati, memegang, mengelus, bahkan memiliki naluri untuk memelihara.

Musfiroh menegaskan anak yang memiliki kecerdasan naturalis cenderung menyukai binatang dan tumbuhan, dan sayang terhadap binatang dan tumbuhan disekitarnya. Dengan menunjukan mereka senang menyiram bunga atau memelihara tanaman dan binatang (Yaumi \&Ibrahim, 2016, hlm. 178).

Kecerdasan naturalis adalah keahlian membedakan hubungan antara beberapa spesies, baik secara formal maupun informal. Memelihara alam dan bahkan menjadi bagian dari alam itu sendiri. Seperti menyiram tanaman, membuang sampah ke tempatnya, menyayangi binatang.

Sementara itu Musfiroh menegaskan bahwa Anak usia 4-6 tahun yang cerdas alam memiliki indikator seperti memiliki minat terhadap alam (dengan mengamati, terlibat, mencermati gambar, mengoleksi unsur tumbuhan, mendokumentasikan melalui gambar, dan mencari informasi dengan bertanya,melihat tayangan dan membaca.)

c. Kegiatan bercocok tanam untuk meningkatkan kecerdasan naturalis

Kegiatan bercocok tanam adalah salah satu kegiatan yang mampu meningkatkan kecerdasan naturalis anak, karena dengan kegiatan ini anak diajak langsung untuk menemui bahan-bahan alam, diantaranya tanah, biji-bijian, pupuk, air. Anak diajak untuk menanam dengan cara terjun langsung ke alam. Tidak banyak anak yang menyukai kegiatan ini karena mereka berfikir bahwa 
kegiatan itu kotor dan akan mengotori pakaian mereka.

Menurut Armstrong dalam Mutaqin (2016, hlm. 35) bahwa cara untuk mengoptimalkan kecerdasan naturalis menggunakan metodemetode pengajaran seperti: akuarium, terrariums, dan ekosistem portabel lainnya, kelas stasiun pemantau cuaca, eco-studi, berkebun, peralngkat lunak yang berorientasi alam peralatan untuk mempelajari alam, video, film alam, jalan-jalan di alam terbuka, hewan peliharaan di dalam ruangan kelas, tanaman sebagai alat peraga.

Kecerdasan naturalis yaitu mencintai keindahan alam, yang dapat dirangsang melalui pengamatan lingkungan, bercocok tanam, memelihara binatang, dan mengamati penomena alam. Memudahkan anak menyukai kegiatan dialam terbuka, mempunyai rasa ingin tahu yang besar dan menguasai ciri-ciri alam sekitar. (Wijana 2014)

Kegiatan bercocok tanam merupakan kegiatan yang direncanakan dan dilaksanakan oleh anak dan guru, kegiatan ini bertujuan menumbuhakan kecintaan anak pada tumbuhan dan lingkungannya. Penting bagi anak-anak untuk belajar dari alam sejalan dengan pendapat Greenman (dalam Ruth Wilshon, $2008 \mathrm{hlm}$. 4) yang menyatakan bahwa The natural environment is an ideal place for children to engage in creative play. relates the following qualities of the natural world to explain why it is so rich in play potential: Nature is universal and timeless, nature is unpredictable, ature is bountiful, nature is beautiful, nature is alive with sounds, nature creates a multitude of places, nature is real, nature nourishes and heals.

Jika diuraikan tentang deskripsi yang dikemukakan di atas, lingkungan alam adalah tempat yang ideal untuk anak-anak menggunakana kreatifitasnya, untuk menjelaskan mengapa alam begitu berpotensial untuk mengembangkan kreatifitas anak diantaranya : alam bersifat universal dan abadi, alam tidak bisa diprediksi, alam itu indah, alam itu melimpah, alam hidup dengan suara, alam menyajikan banyak tempat, alam itu nyata, alam memelihara dan menyebuhkan. Dari penjelasan diatas dapat disimpulkan bahwa kita dapat belajar banyak melalui alam.

Di sekolah juga jarang sekali sekolah yang menyelenggarakan kegiatan yang langsung berhubungan dengan bahan alam untuk merangsang kecerdasan naturalis anak. Oleh karena itu, kita sebagai guru harus banyak memberikan kegiatan yang dapat menstimulus/merangsang kecerdasan naturalis anak.

\section{d. Manfaat Positif Kegiatan Berkebun}

Berikut ini beberapa manfaat positif aktivitas berkebun bagi anak (Ana, 2016):

a) Menumbuhkan kecintaan anak terhadap alam dengan mengenal tanaman dan hewan di sekitar rumah; b) Membuatnya bergerak lebih aktif; c) Belajar memahami proses pertumbuhan; d) Anak juga bisa mengetahui proses menanam, memelihara, memetik dan memasaknya menjadi hidangan lezat di meja makan; e) Dengan menanam di kebun sendiri, Ayah Bunda juga otomatis bisa belajar untuk berkebun dengan benar agar tanaman dapat tumbuh dengan baik.

e. Langkah Kegiatan Bercocok Tanam

Sebelum melakukan kegiatan bercocok tanam guru mempersiapkan bahan dan alat yang diperlukan untuk kegiatan menanam, dan pelaksanaan bercocok tanam di bimbing oleh guru. untuk mulai melaksanakan kegiatan guru mempersiapkan pot berdiameter $15 \mathrm{~cm}$, pastikan bawah pot memiliki lubang peresapan, guru membagikan pot tersebut kepada setiap anak, lalu anak memasukan tanah gembur sebagai media tanam kedalam pot yang sudah diberikan oleh guru, lalu anak diberikan satu biji untuk ditanam, setelah selesai ajak anak untuk menyiram tanaman biji-biji tersebut untuk merawatnya.

Dari kegiatan ini peneliti berharap anak mampu merawat tanaman dan mencintai lingkungannya serta mengetahui perkembang biakan tanaman.

\section{METODE PENELITIAN}

\section{Jenis Penelitian}

Jenis penelitian ini adalah Penelitian Tindakan Kelas. Model PTK yang 
digunakan dalam penelitian ini adalah model Kemmis-Mc. Taggart. Model ini dilakukan melalui 4 langkah yaitu planning (perencanaan), acting (tindakan), observing (observasi), dan reflecting (refleksi). (Syarif dan Asip, 2015, hlm. 5152).

Arikunto S (2010, hlm. 17) mengemukakan empat prosedur penelitian tindakan kelas yaitu :

a. Menyusun rancangan tindakan (planning)

Dalam tahap menyusun rancangan ini, peneliti menentukan fokus peristiwa yang perlu mendapatkan perhatian khusus untuk diamati, kemudian membuat sebuah instrumen pengamatan untuk membantu peneliti merekam fakta yang terjadi selama tindakan berlangsung.

b. Pelaksanaan tindakan (acting)

Penelitian tindakan adalah pelaksanaan yang merupakan implementasi atau penerapan isi rancangan, tindakan di kelas, sehingga pada tahap kedua ini guru harus berusaha menaati apa yang sudah dirumuskan dalam rancangan, tetapi harus berlaku wajar, tidak dibuat-buat. Dalam refleksi keterkaitan antara pelaksanaan dan perencanaan perlu diperhatikan secara seksama agar sinkron dengan maksud semula.

c. Pengamatan (observing)

Pengamatan dilakukan pada waktu tindakan sedang dilakukan. Tahap ini berlangsung dalam waktu bersamaan dengan tindakan.

d. Refleksi (reflecting)

Merupakan tahapan untuk mengemukakan kembali apa yang sudah dilakukan. Kegiatan refleksi ini tepat dilakukan ketika kegiatan pelaksanaan sudah selesai.

\section{Setting Penelitian}

Setting penelitian ini adalah BAMBIM Al-abror Kecamatan
Mangkubumi Kota Tasikmalaya Tahun Ajaran 2016/2017. Waktu penelitian dilakukan pada semester genap bulan April sampai dengan Mei 2017.

\section{Subjek Penelitian}

Subjek Penelitian Tindakan Kelas ini adalah anak kelompok usia 4-5 tahun BAMBIM Al-Abror, Kecamatan Mangkubumi, Kota. Tasikmalaya dengan siswa berjumlah 11 orang anak yang terdiri dari 4 orang anak laki-laki dan 7 orang anak perempuan. Dalam pelaksanaan kegiatan bercocok tanam untuk meningkatkan kecerdasan naturalis, peneliti berperan sebagai pendidik dan Ibu Heni Nurhaeni berperan sebagai guru mitra sekaligus observer.

\section{Variabel Penelitian}

Variabel dalam penelitian ini terdiri dari dua macam, yaitu variabel proses dan variabel hasil. Yang menjadi variabel proses yaitu kegiatan bercocok tanam dan yang menjadi variabel hasil yaitu kecerdasan naturalis.

\section{Teknik Pengumpulan Data}

a. Observasi

Teknik observasi dilakukan untuk membantu peneliti mengetahui sejauhmana perkembangan kecerdasan naturalis anak melalui kegiatan bercocok tanam ini. Selain itu, untuk mengetahui bagaimana guru menggunakan kegiatan bercocok tanam untuk mengembangkan kecerdasan naturalis anak.

Sutrisno dalam Sugiyono (2013, hlm. 203) mengemukakan bahwa, observasi merupakan suatu proses yang kompleks, suatu proses yang tersusun dari berbagai proses biologis dan psikologis. Dua di antara yang terpenting adalah proses-proses pengamatan dan ingatan. 
b. Dokumentasi

Sugiyono (2013, hlm. 329)

Dokumentasi merupakan catatan peristiwa yang sudah berlalu. Dokumen bisa berbentuk tulisan, gambar, atau karya-karya monumental dari seseorang.

Dokumen yang berbentuk tulisan misalnya catatan harian. Dokumen juga bisa berupa gambar. Dokumentasi yang dimaksud peneliti berupa gambar saat proses kegiatan berlangsung.

\section{HASIL DAN PEMBAHASAN}

Berdasarkan permasalahan yang telah dirumuskan, tujuan yang ingin dicapai dalam penelitian ini yaitu:

a. Meningkatkan kinerja guru dalam merancang persiapan pembelajaran melalui kegiatan bercocok tanam untuk meningkatkan kecerdasan naturalis di BAMBIM Al-Abror Mangkubumi.

b. Meningkatkan kemampuan guru mengelola proses pembelajaran melalui kegiatan bercocok tanam untuk meningkatkan kecerdasan naturalis di BAMBIM Al-Abror Mangkubumi.

c. Untuk Mengetahui peningkatan kemampuan kecerdasan naturalis melalui kegiatan bercocok tanam pada siswa BAMBIM Al-Abror Mangkubumi. Dan hasil dari tujuan penelitian ini dipaparkan dalam pembahsan sebagai berikut:

\section{Perencanaan Pembelajaran}

Perencanaan pembelajaran ini dilakukan sebelum melaksanakan tindakan pada setiap siklusnya dengan menyusun $\mathrm{RPPH}$, terdapat tiga RPPH yang digunakan pada penelitian ini, 2 RPPH mempunyai tema dan sub tema yang sama yaitu "Tanah Airku" dengan sub tema "Kehidupan di Desa" dan sub-sub tema "Macam-Macam Pencaharian di Desa (petani kebun)", sedangkan pada siklus III peneliti menggunakan Tema yang berbeda, dikarenakan tema yang sudah direncanakan oleh pihak sekolah sudah selesai oleh karena itu peneliti diberi kesempatan untuk memilih tema yang diinginkan, tema yang dilaksanakan pada siklus III yaitu "Tanaman" dengan sub tema "Tanaman Buah" dan sub-sub tema "Buah Duren"

Adapun hasil peningkatan kemampuan guru dalam perencanaan pembelajaran antara lain dapat dilihat pada gambar diagram dibawah ini:

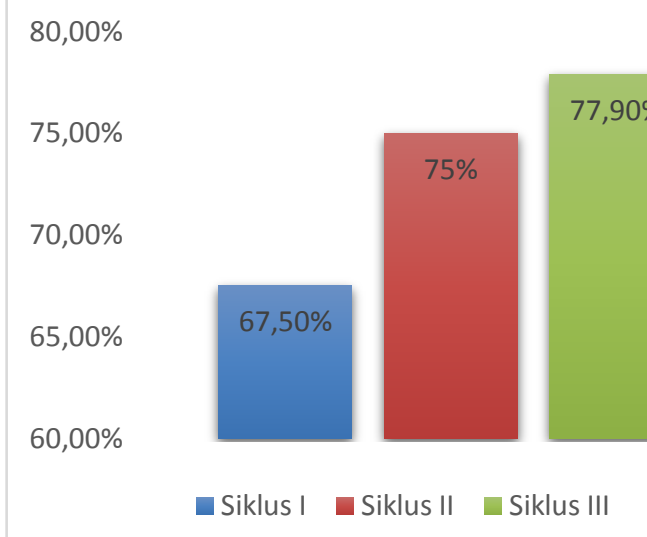

Gambar 4.4 peningkatan kinerja guru dalam perencanaan pembelajaran

Kinerja guru dalam pembuatana RPPH mengalami peningkatan tiap siklusnya, dapat dilihat pada gambar $4 .$. bahwa pada siklus I guru memperoleh nilai dengan persentase $67,5 \%$ belum mencapai kriteria keberhasilan dalam penelitian ini. Kekurangan pada RPPH siklus I ini yaitu kurangnya memanfaatkan media pembelajaran sesuai dengan bidang pengembangan, menentukan cara-cara penanaman pembiasaan pada kegiatan awal, inti, istirahat dan akhir. Pada RPPH siklus II mengalami peningkatan sebesar 7,5\% menjadi $75 \%$ namun pada siklus II juga peneliti masih kesulitan menentukan cara-cara penanaman pembiasaan pada kegiatan, awal, inti, istirahat dan akhir. Namun kekurangan pada siklus I dan II dapat diatasi pada siklus III, sehingga pada siklus III mengalami peningkatan sebesar 
$2,9 \%$ menjadi $77,9 \%$ walaupun hanya mengalami peningkatan sedikit namun kinerja guru dalam perencanaan pembelajaran sudah memenuhi indikator kebehasilan dalam penelitian ini.

\section{Pelaksanaan Kegiatan Bercocok Tanam}

Kegiatan bercocok tanam merupakan pelaksanaan dari penelitian tindakan kelas ini, pada siklus I sampai siklus III peneliti melaksanakan kegiatan bercocok tanam dengan tanaman yang berbeda setiap siklusnya, tujuan dari penelitian ini yaitu melakukan kegiatan bercocok tanam untuk meningkatkan kecerdasan Naturalis anak di BAMBIM Al-Abror.

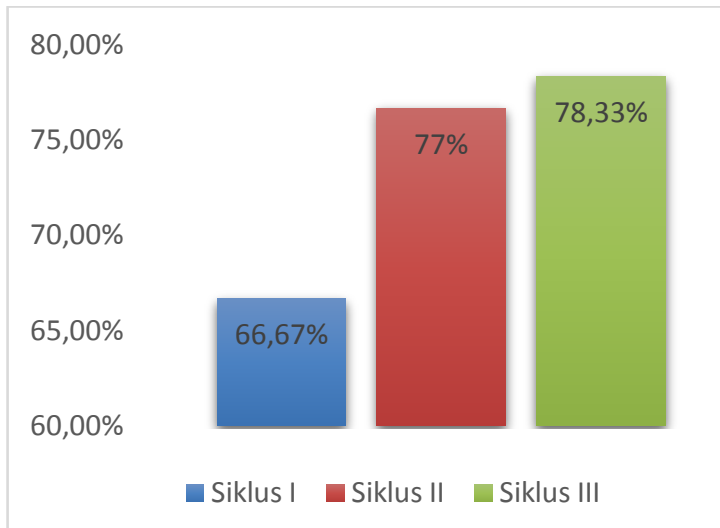

Gambar 4.5 peningkatan kemampuan guru dalam pelaksanaan kegiatan bercocok tanam

Kegiatan bercocok tanam adalah salah satu dari kegiatan yang mampu merangsang kecerdasan naturalis anak. sejalan dengan yang di kemukakan oleh Musfiroh (2010, hlm. 8.7) bahwa anak yang cerdas alam memiliki indikator seperti meiliki minat terhadap alam (mengamat, terlibat, mencermati gambar), merawat dan memelihara hewan dan tanaman, mendokumentasikan melalui gambar dan mencari informasi dengan bertanya melihat tayangan dan membaca.

Kemampuan guru pada siklus I yaitu sebesar $66,67 \%$ dengan kriteria baik, pada siklus II kemampuan guru dalam pelaksanaan kegiatan bercocok tanam meningkat sebesar $10,33 \%$ menjadi $77 \%$, dan pada siklus III mengalami peningkatan lagi sebesar $1,33 \%$ menjadi $78,33 \%$.

\section{Hasil Kecerdasan Naturalis melalui Kegiatan Bercocok Tanam}

Berdasarkan penelitian yang dilakukan oleh peneliti dengan guru kelas BAMBIM Al-Abror sebagai kolaborator yang dilakukan selama tiga siklus menunjukan bahwa kecerdasan naturalis anak BAMBIM Al-Abror melalui kegiatan bercocok tanam ada peningkatan.

a. Menunjukan kesenangan terhadap tanaman

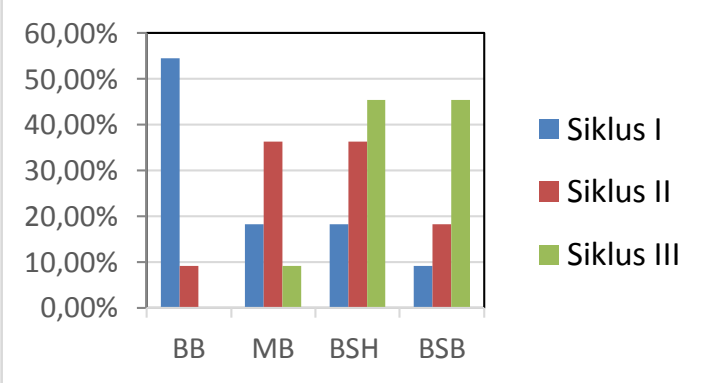

Gambar 4.6 kemampuan anak menunjukan

kesenangan terhadap tanaman

Berdasarkan data di atas dapat dilihat pada indikator menunjukan kesenangan terhadap tanaman pada siklus I ada 54,54\% yang berada pada kriteria BB, 18,18\% pada kriteria $\mathrm{MB}, 18,18 \%$ pada kriteria BSB, dan 9,09\% pada kriteria BSB. Kemudian mengalami peningkatan pada siklus II, anak pada kriteria BB berkurang menjadi 9,09\%, pda kriteria MB mengalami peningkatan yaitu $36,36 \%$, pada kriteria BSH pun sama mengalami peningkatan menjadi $36,36 \%$, pada kriteria BSB hanya ada $18,18 \%$. Pada siklus III pun mengalami peningkatan dengan tidak adanya anak pada kriteria BB, berkurangnya jumlah anak pada kriteria MB sebesar 9,09\%, dan meningkatnya jumlah anak pada kriteria BSH menjadi $45,45 \%$ begitu pula pada kriteria BSB jumlah anak mencapai $45,45 \%$. Sehingga dapat disimpulkan sesuai dengan indikator 
keberhasilan kegiatan ini mampu meningkatkan kesenangan anak terhadap tanaman.

b. Membedakan bagian-bagian tanaman

Gambar 4.7 kemampuan anak

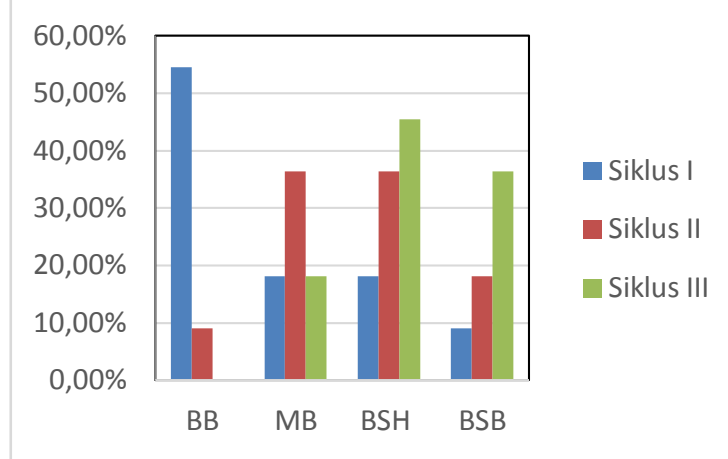

membedakan bagian tanaman

Berdasarkan data di atas pada indikator memedakan tanaman pada siklus I terdapat $54,54 \%$ pada kriteria $\mathrm{BB}$, $18,18 \%$ pada kriteria MB, $18,18 \%$ pada kriteria BSH dan 9,09\% pada kriteria BSB, mengalami peningkatan pada siklus II, dengan ditunjukannya penurunan sebesar 9,09\% pada kriteria $\mathrm{BB}$, dan peningkatan pada kriteria MB sebesar $36,36 \%$, pada kriteria $\mathrm{BSH}$ pun meningkat menjadi $36,36 \%$ begitu pula pada kriteria BSB menjadi 18,18\%. Pada siklus III ada peningkatan dengan ditunjukan tidak adanya jumlah anak yang berada pada kriteria $\mathrm{BB}$ dan menurunnya kriteria $\mathrm{MB}$ menjadi $18,18 \%$, pada kriteria $\mathrm{BSH}$ naik menjadi $45,45 \%$ begitu pula pada kriteria BSB sebesar 36,36\%. Maka dapat disimpulkan, kegiatan bercocok tanam mampu meningkatkan kemampuan anak membedakan tanaman.

c. Kemampuan merawat tanaman

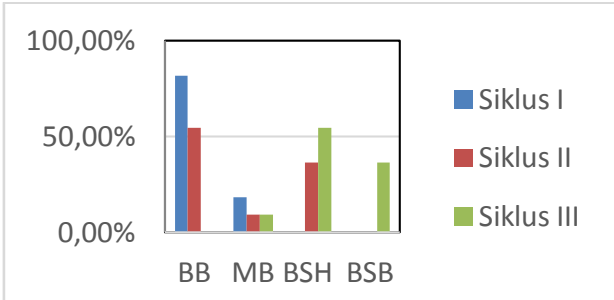

Gambar 4.8 Kemampuan merawat tanaman 
penurunan pada kriteria BB menjadi sebesar $36,36 \%$, dan mulai ada anak yang mencapai kriteria MB sebesar 09,09\% namun pada kriteria BSH siklus II tidak ada anak yang mencapainya, namun ada peningkatan pada kriteria BSB sebesar $54,54 \%$. Dan terdapat peningkatan hingga siklus III dengan menurunya kriteria BB sebesar $18,18 \%$, dan tidak terdapat anak yang berada pada kriteria MB, dan terdapat 9,09\% pada kriteria $\mathrm{BSH}$, pada kriteria BSB pun mengalami peningkatan sebesar $72,72 \%$. Berdasarkan hasil diatas dapat disimpulkan bahwa kemampuan melakukan kegiatan bercocok tanam anak dapat meningkat sesuai dengan indikator keberhasilan.

Peningkatan yang terjadi pada setiap indikatornya menandai bahwa penelitian ini berhasil karena sudah dapat meningkatkan kecerdasan naturalis anak dengan pelaksanaan kegiatan bercocok tanam. Dan sudah memenuhi indikator keberhasilan yaitu sebesar $75 \%$ dari jumlah anak mencapai kriteria $\mathrm{BSH}$.

\section{KESIMPULAN DAN SARAN}

$\begin{array}{ll}\text { Penelitian } & \text { tindakan kelas ini } \\ \text { dilaksanakan di BAMBIM Al-abror }\end{array}$ Kecamatan Mangkubumi Kota Tasikmalaya. Penelitian ini dilaksanakan dengan tiga siklus, setiap siklus dilaksanakan dalam 4 tahapan yaitu: Perencanaan tindakan, Pelaksanaan Tindakan, Observasi dan Refleksi.

Berdasarkan penelitian yang sudah dilaksanakan, dapat disimpulkan bahwa kegiatan bercocok tanam dapat meningkatkan kecerdasan naturalis anak di BAMBIM AlAbror Kecamatan Mangkubumi Kota Tasikmalaya. Hal tersebut dapat terlihat dari meningkatnya jumlah persentase pada setiap aspek di setiap siklusnya, baik dalam perencanaan, pelaksanaan dan kegiatan bercocok tanam anak.

Perencanaan yang dilakukan oleh peneliti sekaligus guru pada penelitian ini mengalami peningkatan setiap siklusnya, dari siklus I ke siklus II dengan kenaikan sebesar 7,5\% dan dari siklus II ke siklus III terdapat kenaikan sebesar 2,9\% sehingga hasil akhir kemampuan gurur dalam merencanakan kegiatan pembelajaran sebesar $77,9 \%$ dengan kriteria baik. Sedangkan untuk pelaksanaan pembelajaran dan kegiatan bercocok tanam dari siklus I ke siklus II mengalami kenaikan sebesar 10,33\% dan dari siklus II ke siklus III mengalami kenaikan sebesar $1,33 \%$ sehingga kemapuan akhir guru dalam pelaksanaan pembelajaran dan kegiatan bercocok tanam sebesar 78,33\% termasuk pada kriteria baik.

Kecerdasan naturalis anak mengalami peningkatan setelah dilakukannya pembelajaran yang dibarengi dengan kegiatan bercocok tanam pada setiap indikatornya, indikator pertama menunjukan kesenangan terhadap tanaman mengalami peningkatan yang signifikan dengan kemampuan akhir sebesar 9,09\% pada kriteria Mulai berkembang, $45,45 \%$ pada kroteria berkembang sesuai harapan, dan $45,45 \%$ pada kriteria berkembang sangat baik. Indikator kedua membedakan bagian-bagian tanaman menalami peningkatan dengan kemampuan akhir sebesar $18,18 \%$ pada kriteria mulai berkembang , $45,45 \%$ pada kriteria berkembang sesuai harapan dan 36,365 pada kriteria berkembang sangat baik. Indikator ketiga kemampuan merawat tanaman mengalami peningkatan dengan kemampuan akhir sebesar $9,09 \%$ pada kriteria mulai berkembang, $54,54 \%$ pada kriteria berkembang sesuai harapan dan $36,36 \%$ pada kriteria berkembang sangat baik. Pada indikator keempat melakukan kegiatan menanam juga mengalami peningkatan dengan kemampuan akhir sebesar $9,09 \%$ pada kriteria berkembang sesuai harapan dan $72,72 \%$ pada kriteria berkembang sangat baik.

Demikian dapat disimpulkan bahwa kegiatan bercocok tanam mampu menarik perhatian anak untuk lebih menyayangi tanaman, mengetahui apa saja bagian tanaman, merawat tanaman.

Saran yang dapat diberikan oleh peneliti berdasarkan hasil penelitian yangtelah dilakukan adalah sebagai berikut:

a. Bagi Guru BAMBIM Al-Abror 
Guru harus mampu memberikan pembelajaran yang kreatif, bervariasi, menarik, dan menyenangkan bagi anak, serta berbasis alam, yang lebih dapat mendekatkan anak dengan alam sehingga kecerdasan naturalis anak dapat berkembang secara optimal.

b. Bagi Peneliti Lanjutan

Bagi peneliti lanjutan, hasil penelitian ini dapat digunakan sebagai salah satu referensi tentang temuan peningkatan kecerdasan naturalis.

\section{DAFTAR PUSTAKA}

Arikunto, S. (2013). Prosedur Penelitian: suatu pendekatan praktik. Jakarta: Rineka Cipta

Chatib dan Said. (2014). Sekolah Anakanak Juara (berbasis kecerdasan jamak dan pendidikan berkeadilan). Bandung: Kaifa

Musfiroh, T. (2010). Perkembangan Kecerdasan Majemuk. Jakarta: Universitas Terbuka

Said, A dan Andi Budimanjaya. (2015). 95 Strategi Mengajar Multiple Intelligences : Mengajar Sesuai Otak dan Gaya Belajar Siswa. Jakarta: Kencana Prenada Group.

Syarif dan Asip, (2015). Penelitian tindakan kelas: teori dan praktik mendesain penelitian tindakan kelas. Tangerang: PT. Pustaka Mandiri

Sujiyono, Y. (2013). Konsep Dasar Penelitian Anak Usia Dini. Jakarta: PT. Indeks 